\title{
AUTOMATION OF BUILDING A CARTOGRAM FOR ECOLOGICAL AND ECONOMIC FEASIBILITY OF THE LANDS WITH THE AGRICULTURAL DETERMINATION
}

\author{
Roman SHULGAN(1 ${ }^{*}$, Oleksandr YANCHUK ${ }^{2}$, Olena KIBUKEVICH ${ }^{3}$ \\ ${ }^{1,3}$ Department of Land Management, Cadastre, Land Monitoring and Geoinformatics, \\ Educational and Scientific Institute Agroecology and Land Management, \\ National University of Water and Environmental Engineering, Rivne, Ukraine \\ ${ }^{2}$ Department of Geodesy and Cartography, Educational and Scientific Institute Agroecology and Land \\ Management, National University of Water and Environmental Engineering, Rivne, Ukraine
}

Received 30 March 2019; accepted 27 February 2020

\begin{abstract}
The conceptual model of automated building of the cartogram of ecological and economic lands feasibility with the agricultural determination has been developed. The coding system for attributive characteristics of agroproductive groups of soils and reliefs has been proposed. The represented concept has been realized in the ModelBuilder module of the software product called ArcGIS with the help of creating an instrument to build the cartogram for the ecological and economic feasibility of lands in an automatic mode. As a result, the instrument, which allows the execution dividing the territory into the feasibility groups of lands, has been received basing on the input raster or vector values.
\end{abstract}

Keywords: ecological and economic estimation, the lands with the agricultural determination, GIS, the profile set of geospatial data, the ModelBuilder module, scientifically grounded rotation of crops, natural cropping capacity.

\section{Introduction}

Increasing the efficiency of using lands as a main method of production in agriculture determines the necessity of looking for the new and currently changing approaches towards organizing the economically beneficial and ecologically safe land use in Ukraine.

The main aim of organizing the rational system for the use of agricultural households lies in creating the necessary spatial conditions on some territory in order to implement the scientifically grounded system of farming and choosing the rotation of crops and the crops themselves within them, which, upon optimal economic indicators, would provide an increase in the households productivity, the widespread renewal of soil fertility, as well as the raise of productivity upon keeping conservation technologies and shaping the ecologically stable agrolandscape together with the system of antierosion methods.

The production value of agricultural households is determined by their capacity to provide the fully functional growth and development of wild and agricultural plants.
Consequently, their organization determines the agricultural assignment and character of using every land section and depends on a variety of causes that limit such application for growing agricultural plants. Among them, the most important ones, such as land conditions and territory relief, are outlined.

To define the qualitative characteristics of land households, correctly locate the landscape rotation of crops and fields of rotation of crops, as well as implement the system of methods by reclamation, enhancement, and transformation of households the cartogram of ecological and economic (ecologically technological) capacity of lands is created.

According to the set feasibility of lands, the selection of the most effective and scientifically grounded rotation of crops occurs; as a result of this, the intensive agricultural production will be concentrated on highly qualitative soils, which to the least fall under the antierosion processes; and, thus, the eroded soils are used with the implementation of land protective system of farming together with growing agricultural plants that have soil protective

${ }^{*}$ Corresponding author. E-mail: r.b.shulhan@nuwm.edu.ua 
capabilities or will be taken away from the composition of farming lands.

Using GIS for the automation of building the cartogram of ecological and economic capacity of lands will allow a more accurate consideration of the soils conditions and territory relief. With the help of the presented development, it will be possible to further automatically select the most efficient and scientifically grounded rotation of crops by the way of modeling their implementation on the territory.

\section{Analysis of research}

The wide range of activities, which are related to evaluate the land conditions with the agricultural determination and use of geoinformational systems, should be noted. Many of them propose the application of classification algorithm and zoning of agricultural lands basing on the list of causes.

Particularly, in the research (Shulgan et al., 2017), the algorithm of automated natural and agricultural regionalization has been represented. The example of approbation of the proposed algorithm by building the green-model of the territory part has been provided. Uniting spots basing on their calculated weight coefficients has been done with the use of the "natural groups" method. The developed method allows periodically executing the correction of regional limits depending on the change in the land state and their indicators as a result of the more detailed analysis of natural conditions in this region.

Analogically, the cartogram of ecological and economic feasibility of lands demands the review and clarification with some time that will be easily provided if there is an automated system.

For example, in the research (Nguyen et al., 2015), the stepped approach towards the geoinformational analysis of lands feasibility depending on different criteria, which include the agroecological capacity, impact on the environment, as well as socio-economic applicability via the algorithm uniting the selected indicators, their evaluation, and weight with functional mathematic combinations has been developed. As a result, the classification of efficiency indicators, according to the class of adequacy, impact, and technical economic grounds, has been received; and the class of feasibility of land use has been determined.

In the article (Elsheikh et al., 2013), the ALSE system and the intellectual system of evaluating the suitability of lands for different types of crops in tropical and subtropical regions (e.g., mango, banana, papaya, citrus and guava) basing on geoecological factors, which automate the process of evaluation and illustrate the results in the table of attributes, have been presented.

The aim of research (AbdelRahman et al., 2016) lies in the development of the method to evaluate the capacity of lands use, which will help for land owners and planners of land use to determine the regions with restricting a variety of determined types of land applications. Geodesic data and the results of field activities have been integrated in the evaluation of the lands use feasibility basing on GIS for the agricultural planning in the district of Chamaradzhanar, Karnataka, India. Except this, GIS was used for implementing the suitability for growing main plants, as well as the quality and characteristics of land. Different parameters of land quality, i.e.: the type of soil, the deepness of laying humus horizon, erosion, fall, floods, and the mechanical composition of soil under different land units have been assessed for agricultural plants. Later, they were integrated with the consequence of logical operations to create the cards of land suitability. For illustrating these stages of capacity, the cards of feasibility and possibilities for each land use have been developed; and the spatial presentations of soils that are capable for agriculture have been shown.

The aim of investigation (Mokarram \& Mirsoleimani, 2018) is the determination of lands feasibility for growing citrus plants in the province of Fars, Iran. For achieving the mentioned goal to prepare an imprecise card of each parameter in GIS, the theory of fuzzy sets and order weight average (OWA) has been applied. Initially, such parameters were used as: the availability of water (well, spring and river), the network of roads, slope exposition, height, slope, maximum temperature, minimum temperature, the amount of rainfalls, the relative air humidity, the hours of sun rays and the growing degree days (GDD), as the input values. After the preparation of interpolation card with the help of IDW for each layer, the imprecise card was prepared, while using the function of vague belonging. Therefore, basing on the level of importance of any information, the method of analytical hierarchical process (AHP), which defines the weight for each layer and feasibility of lands, is being applied.

Therefore, considering the provided results of investigations, the system approach towards the selection of the system of factors and taking in consideration their weights, while solving the classification tasks and territory zoning, should be noted. Also, the wide application of GIS means, while deciding on land feasibility with the various target determination, should be emphasized. However, currently, we have not received any publications describing the algorithm of cartogram automation of ecological and economic applicability. Basing on the analysis of displayed experience while solving analogical tasks, we consider appropriately to apply the software complex ArcGIS, as it allows creating the geoprocessing instruments in the ModelBuilder module.

ModelBuilder is a visual programming language for building geoprocessing workflows. Geoprocessing models automate and document your spatial analysis and data management processes. You create and modify geoprocessing models in ModelBuilder, where a model is represented as a diagram that chains together sequences of processes and geoprocessing tools, using the output of one process as the input to another process (What is ModelBuilder?, n.d.). 


\section{Research methods}

The aim of research lies in the development of the automation model of building the cartogram of ecological and economic lands feasibility with the agricultural determination.

As it has been mentioned above, to build the cartogram of ecological and economic feasibility the data on soil conditions and territory relief are needed. In order to obtain the automation of building the cartogram of ecological and economic feasibility, the software complex ArcGIS and the ModelBuilder providing a possibility in order to create the own specialized models or scripts for a sequential launch of instruments has been used.

Taking into consideration the fact that there is a big amount of agroproduction groups and their cancellations (more than 200), it is quite complicated automatically to determine their ecological and economic feasibility. One and the same agrogroup depending on the slope could be suitable as arable land, soil protective rotation of crops, tinning and underflooring. That is why it is necessary to propose the system of coding of agrogroups and slopes; it gives a possibility to automatically define technological feasibility groups.

We propose to execute the coding of agroproduction groups according to their technological feasibility upon the condition of the best use (feasibility). Only 6 groups of feasibility are applied; the agrogroups by their possible application belong there (Kornilov, 2005; Odariuk et al., 2010) (Table 1). This list of feasibility groups has been developed according to the investigated territory and could be widespread if needed by other codes.

Table 1. Coding of agroproduction groups of soils (agroproduction groups of soils for the investigated territory have been provided)

\begin{tabular}{|c|c|c|}
\hline Scale & Feasibility groups & Codes of agrogroups \\
\hline 1 & $\begin{array}{l}\text { Lands that are suitable for } \\
\text { arable for locating field } \\
\text { rotation of crops }\end{array}$ & $\begin{array}{l}29 г, 40 г, 41 г, 49 г, 52 г, \\
55 г, 134 г, 208 г, 208 д\end{array}$ \\
\hline 2 & $\begin{array}{l}\text { Lands that are suitable } \\
\text { for arable for locating soil } \\
\text { protective rotation of crops }\end{array}$ & 50г, 51д, 56г, 57д, \\
\hline 3 & $\begin{array}{l}\text { Arable lands that demand the } \\
\text { constant tinning }\end{array}$ & 132,132 д \\
\hline 4 & Lands for reforestation & \\
\hline 5 & Disturbed lands & $217 \Gamma$ \\
\hline 6 & $\begin{array}{l}\text { Lands that are suitable under } \\
\text { agricultural households after } \\
\text { executing deep melioration } \\
\text { of lands }\end{array}$ & 141,212 \\
\hline
\end{tabular}

In order to have a possibility for executing the spatial analysis the following proportionate system of codes for relief by the slopes of the territory has been selected (Table 2).
Table 2. Coding of slopes

\begin{tabular}{|c|l|c|}
\hline Scale & \multicolumn{1}{|c|}{ Feasibility } & Slope \\
\hline 1 & $\begin{array}{l}\text { Lands that are suitable for } \\
\text { arable for locating field } \\
\text { rotation of crops }\end{array}$ & $0-3^{\circ}$ \\
\hline 2 & $\begin{array}{l}\text { Lands that are suitable } \\
\text { for arable for locating soil } \\
\text { protective rotation of crops }\end{array}$ & $3-7^{\circ}$ \\
\hline 3 & $\begin{array}{l}\text { Arable lands that demand the } \\
\text { constant tinning }\end{array}$ & $7-10^{\circ}$ \\
\hline 4 & Lands for reforestation & More than $10^{\circ}$ \\
\hline
\end{tabular}

The allocation of feasibility groups basing on the developed codes of agrogroups and slopes is proposed to be executed with the help of the method of weighted overlay (Weighted Overlay) (How Weighted..., n.d.).

In its basis, there is a standard mechanism of analyzing overlay, which allows solving the tasks with the consideration of several criteria and their weight. In this case, the search of feasible lands for the agricultural use by two criteria will be executed.

The action of the instrument includes the following steps:

- Reclassification of the values of input raster by the general scale of feasibility evaluation;

- Multiplication of the values of cells of each input raster for the raster weight;

- Adding cells for receiving the resulted raster.

The layers of input criteria in different number systems with different diapasons should lead to a single scale. This task has been solved with the help of the proposed coding (Tables 1,2). Also, any class may have the value Restricted as assigned (Restricted); it means that the appropriate areas are not suitable or may not be applied in the analysis.

As a result of using the instrument of weighted overlay (Weighted Overlay), we get the separate rasters for each feasibility group, where within every group of soils feasibility the capacity by slopes has been determined.

At the next stage, they should be united into one resulting raster. For this purpose, we offer using the Plus function (Plus), which sums up the values of two rasters by the principle of cell after cell.

The received result contains very tiny contours, which are stipulated by the cell size; that is why the value should be generalized. Let's use the instrument "Majority Filter", which replaces the values of raster cells, basing on the values of majority of nearest cells.

\section{The results of the research}

The object of investigation was the territory of Bohdashiv country council of Zdolbuniv district of Rivne region in Ukraine. The object selection is stipulated by a variety of agroproduction groups of soils and the expressed relief forms.

In this research, in order to build the cartogram shpfiles have been used, i.e. the limits of agroproduction groups of soils of all agricultural households within the 
investigated territory; and the horizontals with the corresponding sections. The codes of agrogroups and heights of horizontals are input into the attributive information of files. Also, the codes according to the developed scale have been input in the attributive information of agroproduction groups of soils (Table 1).

For the realization of the proposed approach, it is necessary to prepare input values in the corresponding way.

For the beginning, the digital elevation model (DEM) by the current horizontals should be created (Figure 1). We use at the meantime the instrument "Topo to Raster" ("Topo to Raster"). Among the available parameters of the instrument, we should choose the input vector values this is a layer with horizontals, the size of input cell is
$5 \mathrm{~m}$, and the output extent is a layer with the limit of the analyzed village council.

The next step will be the estimation of slope with the help of the instrument "Slope", the input value of which is the raster received during the preceding stage.

Then, we cut off the received result by the border of the village council with the help of the instrument "Clip".

For the further use, it is necessary to execute the reclassification of received slopes, according to the proposed scale (Table 2) - we provide 4 classes of classification with the limit values 3, 7, 10 degrees via the instrument "Reclassify" (Figure 2).

This way, the values of relief are prepared for the further use in creating the cartogram of lands feasibility.

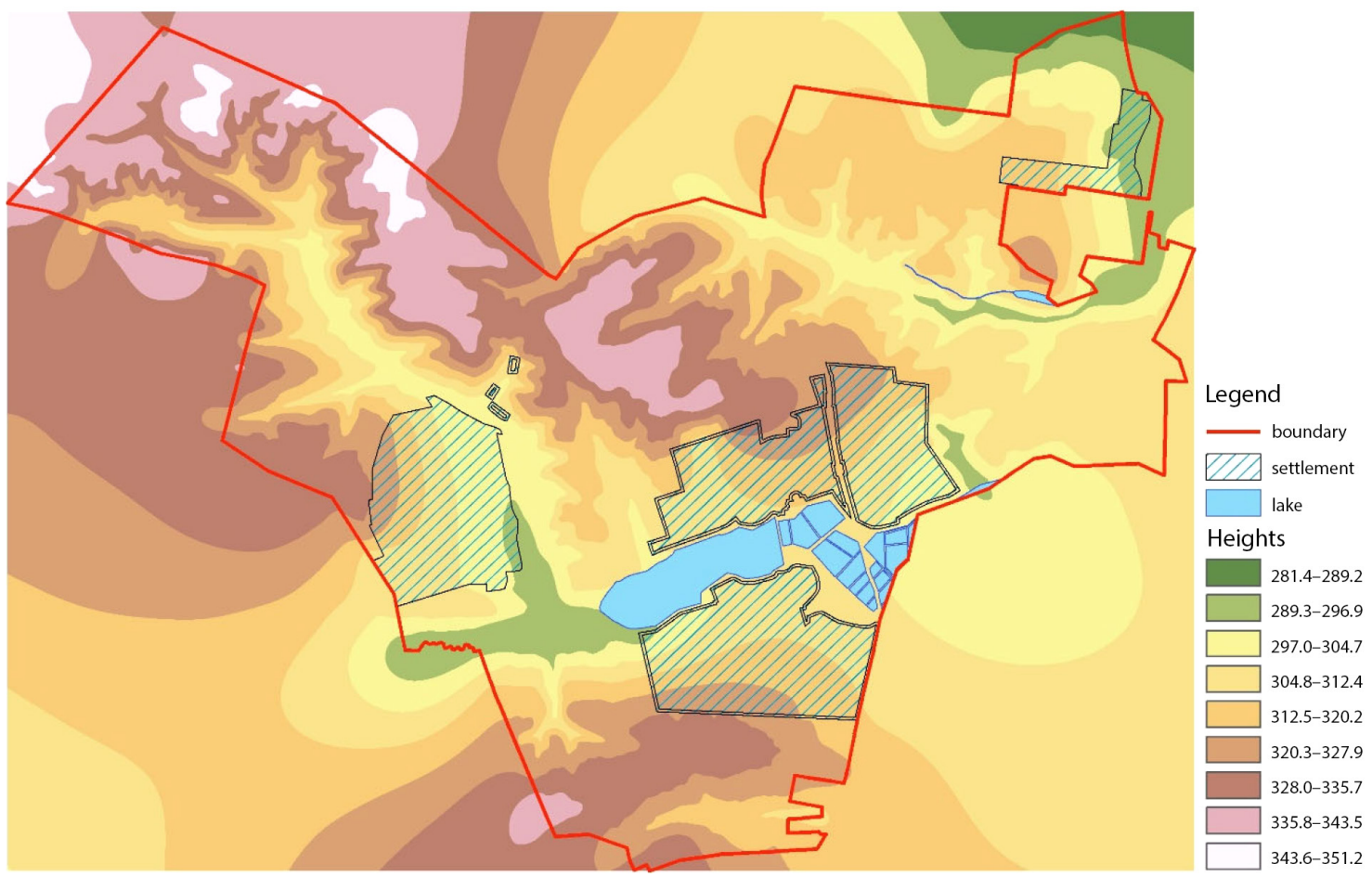

Figure 1. DEM of the territory of the village council

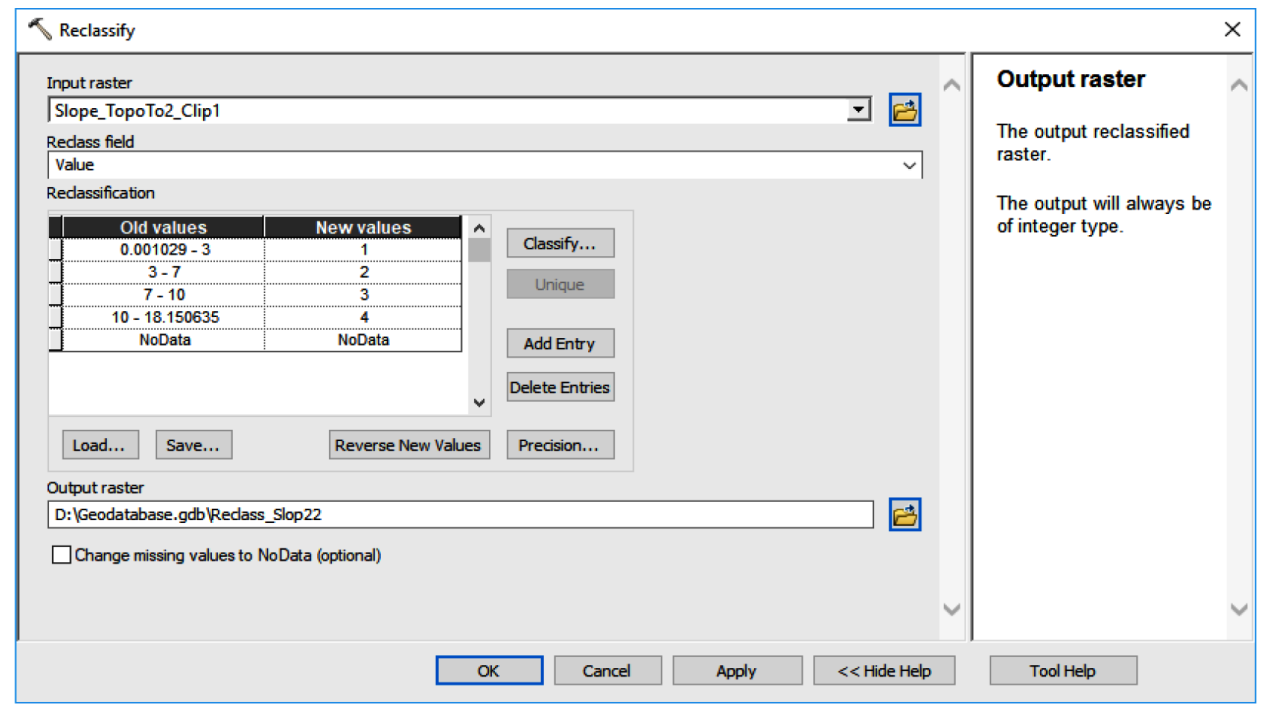

Figure 2. Reclassification of slopes according to the proposed scale 
For the preparation to the further use of values about agrogroups, it is necessary to transfer them into the raster basing on the attributive values of their codes. For this, we use the instrument "Polygon to raster", with the following parameters: input objects - the layer with agrogroups, the field of values - that is the field that we were creating and filling in with the feasibility codes, the method of assigning a value to a cell is chosen "MAXIMUM_COMBINED_AREA" - is the method that will be assigning that code to the agrogroup, the area of which prevails in the frame of the cell, and as well the desired cell size is $5 \mathrm{~m}$.

After the corresponding preparation of relief data and agrogroups we should transfer to the creation of the cartogram of ecological and economic feasibility of lands. Basing on the receiver raster images of relief and soils agrogroups we should execute the weighted overlay of these rasters. For this, we should use the instruments described above ("Weighted Overlay"), in which it is necessary to indicate the input rasters and their weights, set the evaluation scale, and the value of scale (Figure 3 ).

We will demonstrate the used approach on the examples. The first example of selecting the sections that are suitable for the field rotation of crops should be analyzed. We will add the raster with relief; and the next one should be the raster with agrogroups. The percentage of impact that we should leave is $100 \%$ for the relief and $0 \%$ - for agrogroups. Therefore, agrogroups should be used only for setting limits, for which the analysis will be provided, and the cell feasibility within these sections will be determined only by the relief characteristics. The evaluation scale is chosen from 1 to 6 with the step 1. It should be exactly six because at the very start (Table 1) we have selected 6 groups of land feasibility.

In the working window of the instrument for the raster with relief, we should set the scale value according to the values in the column "Field", and for the raster with agrogroups the value of scale for "1" should be set; all the rest should be restricted, while setting the status "Restricted". It will allow for the agrogroups that are suitable for arable (the code 1 in the Table 1) setting their suitability by slope. Depending on the slope, these soils could be suitable for various uses.

In the next example, we will analyze the selection of sections for locating soil protective rotation of crops. We are adding the rasters with relief and soils and set their corresponding weights $(100 \%$ and $0 \%)$. In the working window of the instrument for the raster with relief for the cell with the value " 1 " in the column "Field", we are setting the value "2" in the column "Scale Value", and the following ones should be added according to the values in the column "Field". For the raster of agrogroups, the scale value for "2" should be set as "2"; all the rest should be restricted with setting the status "Restricted" (Figure 4). Analogically, the values for the following feasibility groups of soils should be set.

This way, the separate rasters for each feasibility group have been received. To form the cartogram of ecological suitability they should be united into one layer. In order to do this, the instrument "Plus" has been used ("Plus").

The received result at this stage rather precisely displays the suitability of each cell though it contains many tiny contours, which consist of several cells. In a practical use, such tiny contour pattern is not justified as these contours are too small for forming agricultural fields. Therefore, to remove this drawback the generalization of results with the help of the instrument "Majority filter" should be applied ("Majority filter") (Figure 5).

For the convenience of further work with the cartogram, the received result could be converted into shpfiles with the application of the commands "Raster to

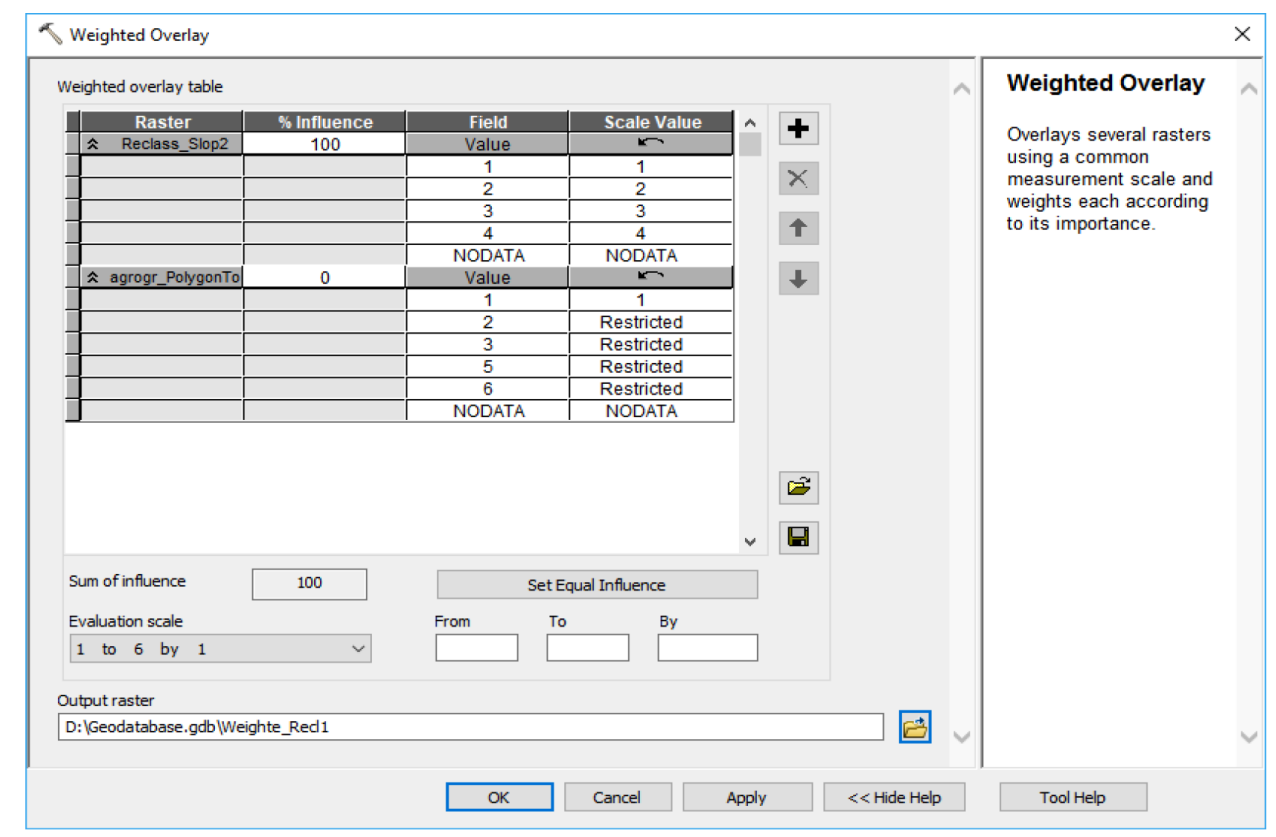

Figure 3. Working window of the instrument "Weighed Overlay" with the parameters for field rotation of crops 
polygon" and "Feature class to shapefile (multiple)".

For the automated setting of the necessary colors for each class of lands feasibility (Kornilov, 2005; Odariuk et al., 2010) the instrument "Apply symbology from layer" has been used.

The received cartogram of lands feasibility of the village council that appeared due to the developed instrument in the process of work is provided in the Figure 6.

For the comparison, the cartogram of ecological and economic feasibility within the territory of the village council has been created by a specialist in a manual mode (Figure 7).

From the visual comparison of provided cartograms it is clear that the group contours of lands feasibility, in general, repeat the contours determined by the specialist. The received contours are less smooth that means the more accurate determination of suitability by slopes.
The described algorithm has been realized in the application ModelBuilder; it is a language of visual programming for the creation of working processes of geoprocessing. As a result, the instrument for the automated building of the cartogram of ecological and economic feasibility of lands with the agricultural determination has been received (Figure 8).

\section{Conclusions}

In this research, the conceptual model of automated building of the cartogram of ecological and economic lands feasibility with the agricultural determination has been developed. The coding system of agrogroups and relief feasibility has been proposed; it will allow executing the further automated classification with the help of the software product.

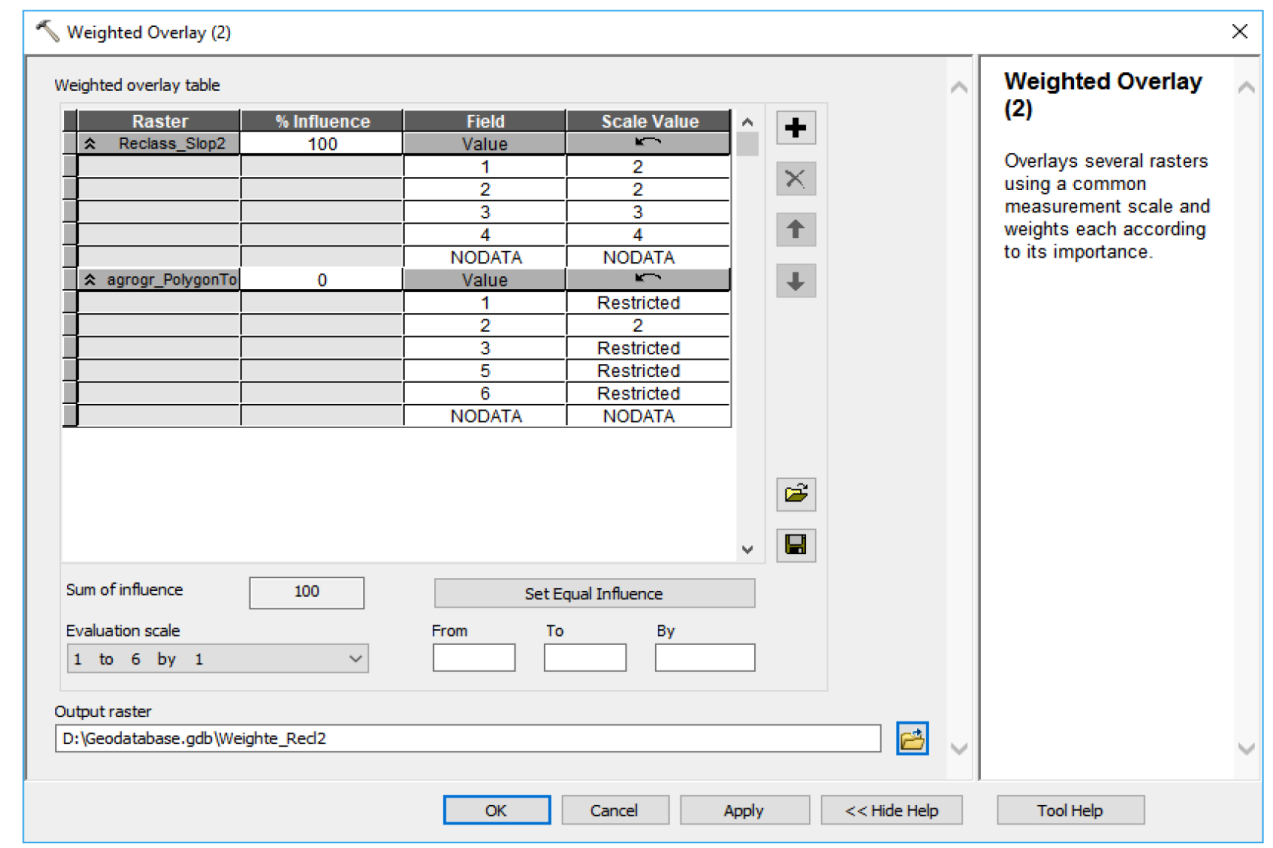

Figure 4. Working window of the instrument "Weighted Overlay" with the parameters for soil protective rotation of crops
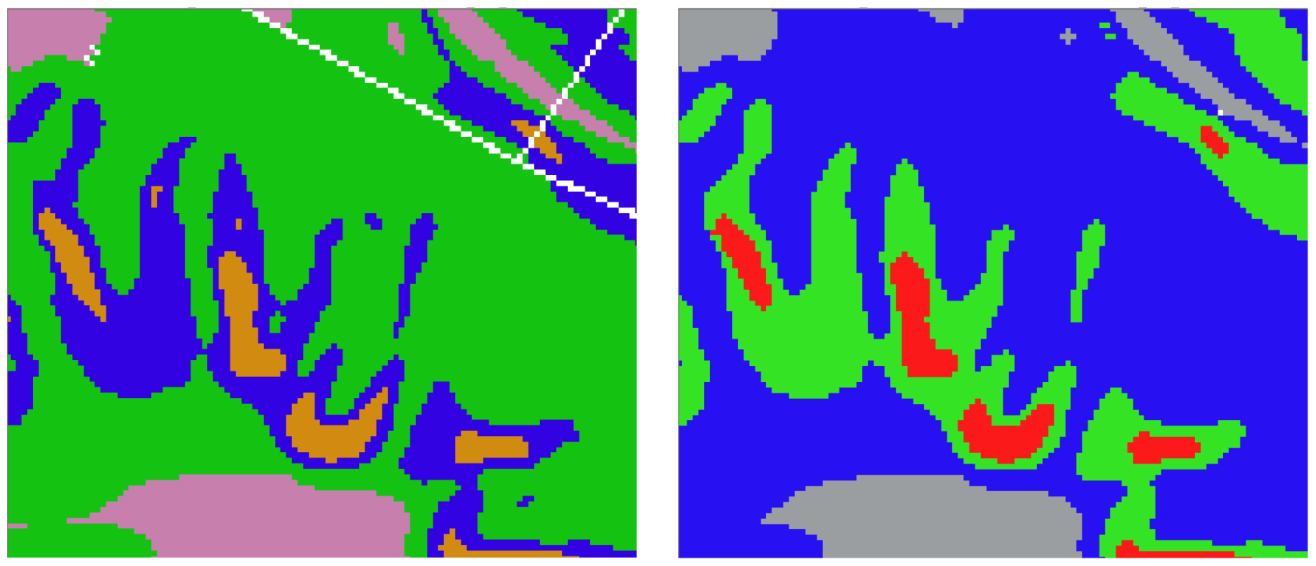

Figure 5. Example of activity of the instrument "Majority filter" - is a fragment of the territory for using the instrument (in the left side) and after its application (in the right side) 


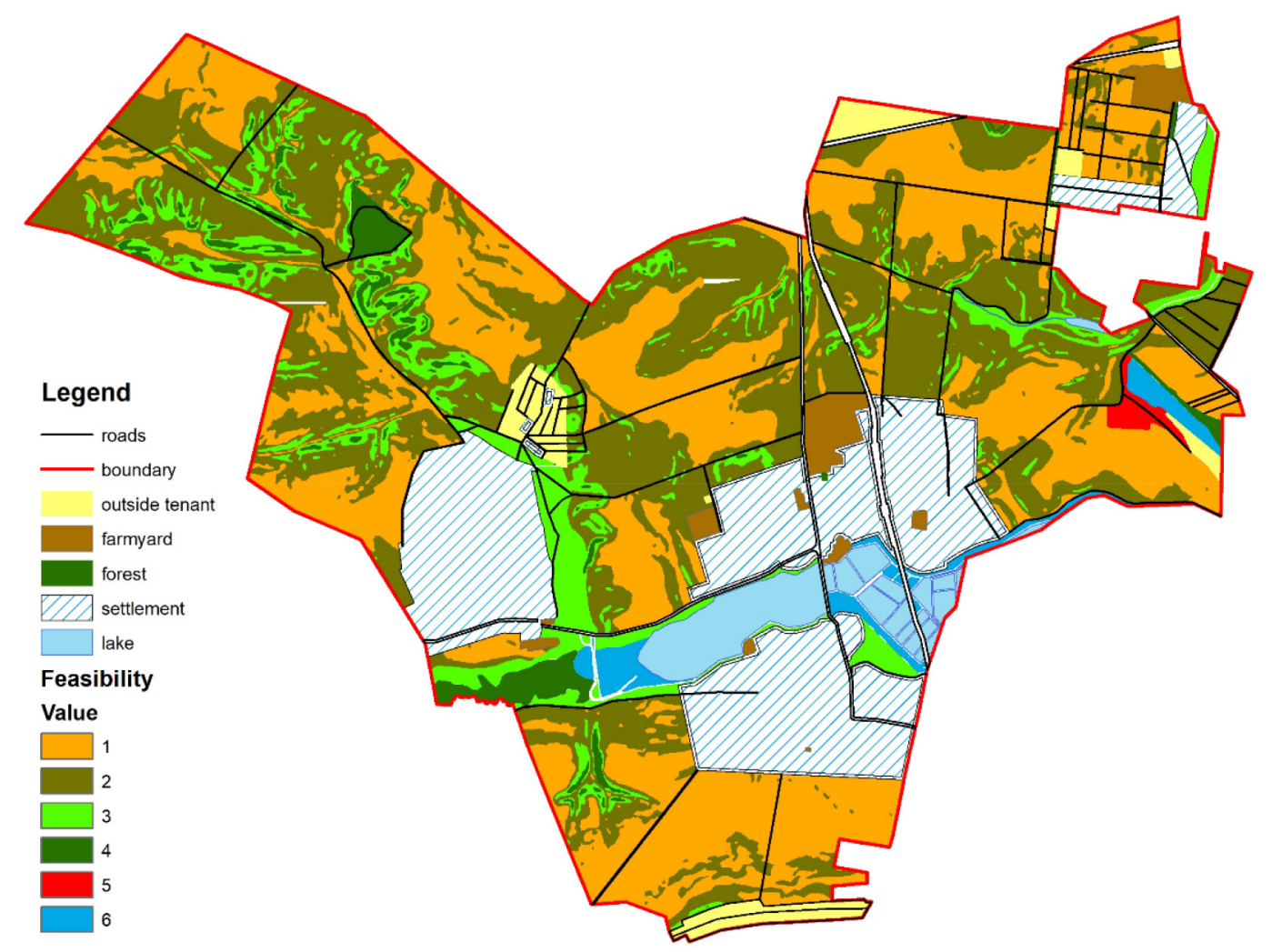

Figure 6. Cartogram of lands feasibility of the village council has been created in an automatic mode (scale of feasibility value is in table 1)

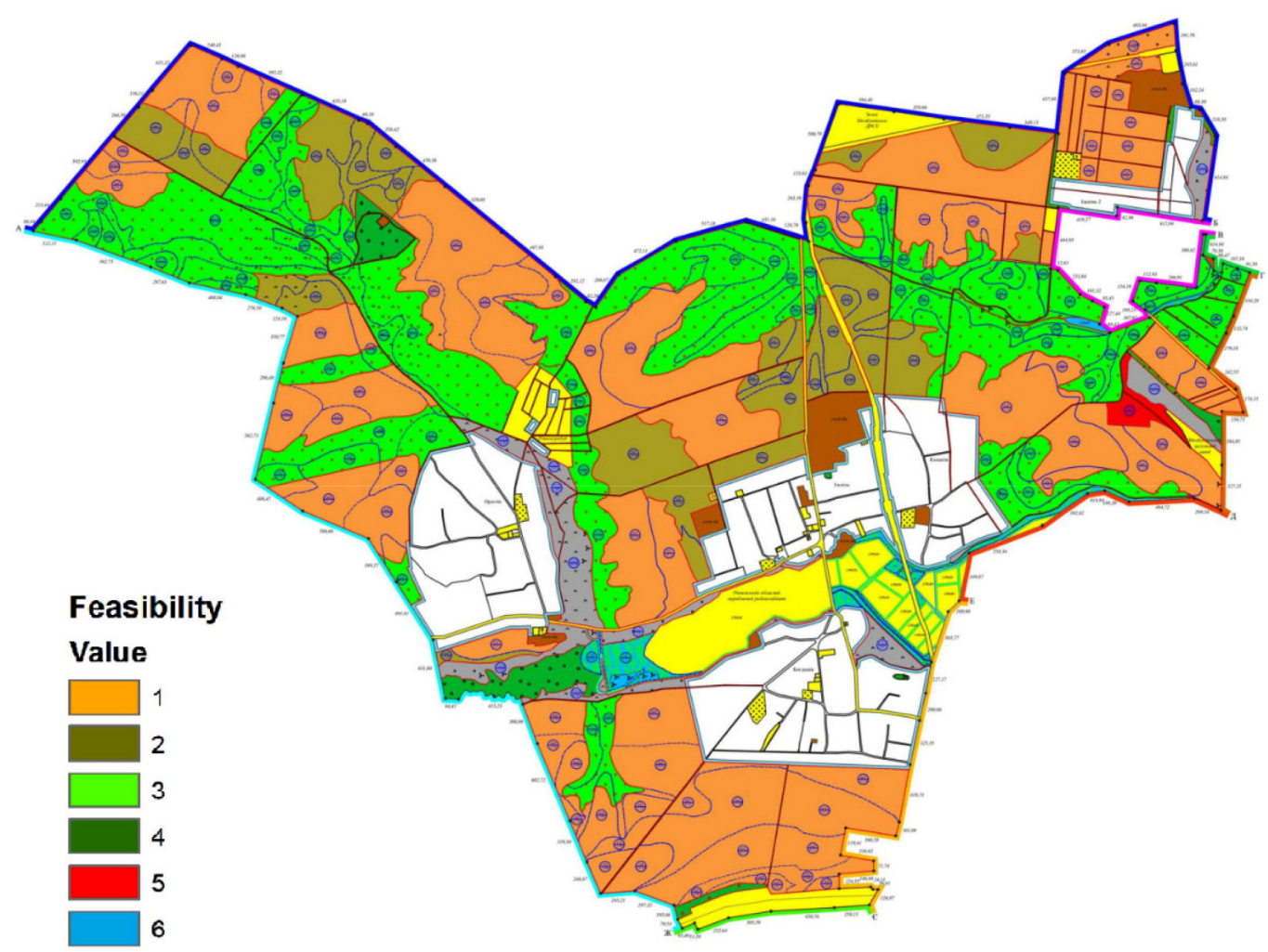

Figure 7. Cartogram of lands feasibility of the village council has been created by a specialist (scale of feasibility value is in Table 1) 


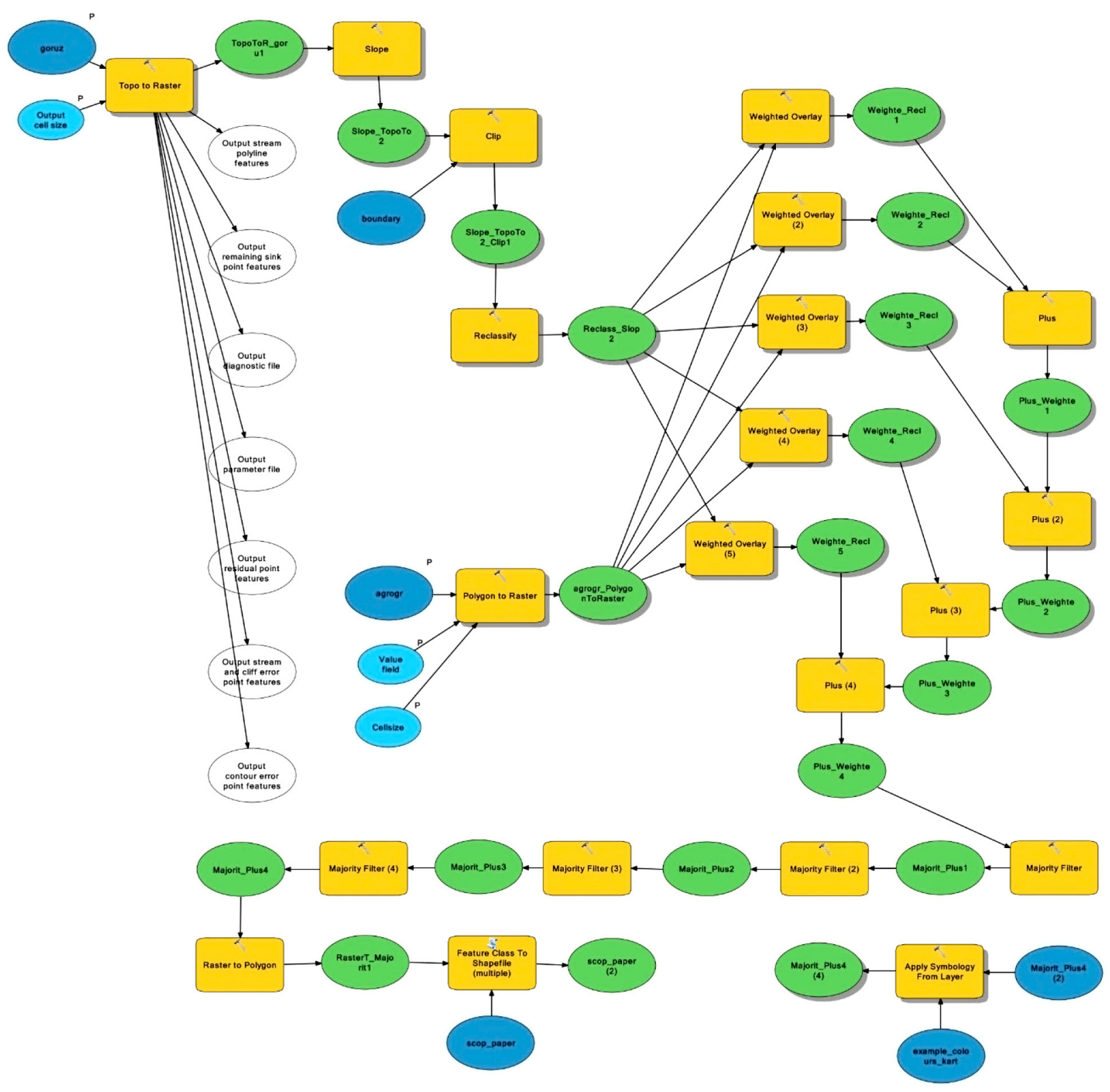

Figure 8. Model of geoprocessing to build the cartogram of lands feasibility with the agricultural determination

The developed model has been realized in the environment of ModelBuilder. As a result, the instrument, which allows the execution dividing the territory into the feasibility groups of lands, has been received basing on the input raster or vector values.

Therefore, the use of the automated algorithm allows decreasing the time expenditure for building the cartogram, removes the impact of a human factor while calculating slopes, and increases the accuracy of building the contours of feasibility groups.

\section{References}

AbdelRahman, M. A. E., Natarajan, A., \& Hegde, R. (2016). Assessment of land suitability and capability by integrating remote sensing and GIS for agriculture in Chamarajanagar district, Karnataka, India. The Egyptian Journal of Remote Sensing and Space, 19, 125-141.

https://doi.org/10.1016/j.ejrs.2016.02.001

Elsheikh, R., Shariff, A. R. M., Amiri, F., Ahmad, N., Balasundram, S. K., \& Soome, A. M. (2013). Agriculture Land Suitability Evaluator (ALSE): A decision and planning support tool for tropical and subtropical crops. Computers and Electronics in Agriculture, 93, 98-110.

https://doi.org/10.1016/j.compag.2013.02.003

How Weighted Overlay works. (n.d.). Retrieved November 14, 2018, from http://desktop.arcgis.com/en/arcmap/10.3/tools/ spatial-analyst-toolbox/how-weighted-overlay-works.htm

Kornilov, L. (2005). Zemlevporiadne proektuvannia. Metodyka vykonannia rozrakhunkovo hrafichnykh robit ta kursovykh proektiv: navchalnyi posibnyk. Kondor (in Ukrainian). 
Mokarram, M., \& Mirsoleimani, A. (2018). Using Fuzzy-AHP and order weight average (OWA) methods for land suitability determination for citrus cultivation in ArcGIS (case study: Fars province, Iran). Physica A: Statistical Mechanics and its Applications, 508, 506-518. https://doi.org/10.1016/j.physa.2018.05.062

Nguyen, T., Verdoodt, A., Tran, V., Delbecque, N., Tran, T., \& Van Ranst, E. (2015). Design of a GIS and multi-criteria based land evaluation procedure for sustainable land-use planning at the regional level. Agriculture, Ecosystems \& Environment, 200, 1-11. https://doi.org/10.1007/s40808-018-0499-9
Odariuk, T., Rusina, N., \& Baseniuk, T. (2010). Zemlevporiadne proektuvannia: navchalnyi posibnyk. Agrarna osvita (in Ukrainian).

Shulgan, R., Kibukevich, O., Yanchuk, O., \& Nikolaichuk, K. (2017). GRID-model of natural agricultural zoning. Geodesy and Cartography, 43(1), 22-27.

https://doi.org/10.3846/20296991.2017.1299844

What is ModelBuilder? (n.d.). Retrieved December 10, 2018, from http://pro.arcgis.com/en/pro-app/help/analysis/geoprocessing/modelbuilder/what-is-modelbuilder-htm 